\title{
FISH-OIL PRECONDITIONING MODULATES PLASMA MCP-1 AND TIMP-1 LEVELS AFTER EXPERIMENTAL INDUCED TRANSIENT CEREBRAL ISCHEMIA
}

\author{
ADINA HUȚANU ${ }^{1,2}$, EMOKE HORVATH ${ }^{3}$, ALEX ORĂDAN ${ }^{4}$, SEPTIMIU VOIDĂZAN ${ }^{5}$, LIVIU $^{2}$ \\ CHIRIAC $^{6}$, DANIELA LUCIA MUNTEAN $^{7} *$ MINODORA DOBREANU $^{1,2}$ \\ ${ }^{1}$ University of Medicine and Pharmacy of Târgu Mureș, Târgu Mureș, Romania \\ ${ }^{2}$ Center for Advanced Medical and Pharmaceutical Research Târgu Mureș, Târgu Mureș, Romania \\ ${ }^{3}$ Pathology Department, University of Medicine and Pharmacy, Târgu Mureș, Romania \\ 4 "Iuliu Hațieganu” University of Medicine and Pharmacy, Center for Animal Facility, Cluj-Napoca, Romania, \\ ${ }^{5}$ Department of Epidemiology, University of Medicine and Pharmacy Târgu Mureș, Romania \\ ${ }^{6}$ National Magnetic Resonance Center, Faculty of Physics, Babeș-Bolyai University, Cluj-Napoca, Romania \\ ${ }^{7}$ Department of Analytical Chemistry and Drug Analysis, University of Medicine and Pharmacy, Târgu Mureș, Romania
}

*corresponding author: danielaluciamuntean@yahoo.com

Manuscript received: January 2018

\begin{abstract}
The aim of the study was to assess the dynamic changes in cytokines profile and their correlation to immunohistochemistry brain modifications after transient middle cerebral artery occlusion (tMCAO) in saline-treated ischemic rats compared to fish oil preconditioned rats. 30 Wistar male adult rats randomly divided into sham $(\mathrm{n}=10)$, ischemic $(\mathrm{n}=10)$, and fish oil $(\mathrm{FO})(\mathrm{n}=$ 10) groups underwent tMCAO using a silicone monofilament technique with a minimum invasive procedure. Blood was withdrawn at $6 \mathrm{hrs}$ and $24 \mathrm{hrs}$ after reperfusion, and ischemia was verified $24 \mathrm{hrs}$ after reperfusion by MRI (magnetic resonance imaging) acquisition. Neurological assessment was performed using a five-point scale. Five cytokines (TNF-alfa, IL6, TIMP-1, MCP-1, and VEGF) were simultaneously analysed using the multiplex immunoassay based on xMAP (multianalyte profiling) technology. Plasma concentration of TIMP-1 was higher in ischemic and FO group compared to sham, 6 hrs after reperfusion; in the ischemic group, the concentration of TIMP-1 raised significantly at $24 \mathrm{hrs}(37.28 \pm 4.85 \mathrm{pg} / \mathrm{mL})$ compared to FO group $(14.11 \pm 1.79 \mathrm{ng} / \mathrm{mL}), \mathrm{p}<0.0001$. Plasma MCP-1 concentration did not differ between sham $(0.69 \pm$ $0.18 \mathrm{pg} / \mathrm{mL})$ and FO group $(0.798 \pm 0.060 \mathrm{pg} / \mathrm{mL})$, while in the ischemic group level was significantly higher $(1.627 \pm 0.19$ $\mathrm{pg} / \mathrm{mL}), \mathrm{p}=0.0001$. Whilst in the ischemic group, concentrations were elevated at both points of measurement, in the FO group the level significantly decreased after $24 \mathrm{hrs}(\mathrm{p}=0.0005)$. Omega 3 PUFA (polyunsaturated fatty acid) decreased plasma MCP-1 level, a key cytokine involved in the inflammatory cell migration. Additionally, in Omega 3 preconditioned group, TIMP-1 expression was lower, probably due to a lower activation of matrix metalloproteinases.
\end{abstract}

\section{Rezumat}

Scopul studiului a fost evaluarea modificărilor în dinamică a 5 citokine, precum şi corelaţia cu modificările imunohistochimice după ischemia indusă de ocluzia temporară a arterei cerebrale medii, la șobolanii cu și fără precondiționare cu ulei de pește. 30 șobolani masculi, adulți, rasa Wistar, randomizați în grupul control $(\mathrm{n}=10)$, ischemic $(\mathrm{n}=10)$ și cu administrare prealabilă de ulei de pește $(\mathrm{FO})(\mathrm{n}=10)$, au fost supuși ischemiei cerebrale tranzitorii folosind tehnica minim invazivă cu monofilament intraluminal. Sângele a fost recoltat la 6 şi la 24 ore după reperfuzie, iar controlul ischemiei s-a realizat imagistic la 24 ore. Evaluarea neurologică a fost făcută cu o scală de 5 puncte. Cinci citokine (TNF-alfa, IL6, TIMP-1, MCP-1 și VEGF) au fost analizate folosind tehnica multiplex bazată pe tehnologia xMAP. Concentrația plasmatică a TIMP-1 a fost mai mare la grupul ischemic și FO, comparativ cu grupul control la 6 ore după reperfuzie; în grupul ischemic concentrația TIMP-1 a crescut semnificativ după 24 ore $(37,28 \pm 4,85 \mathrm{pg} / \mathrm{mL})$, comparativ cu grupul FO $(14,11 \pm 1,79$ $\mathrm{ng} / \mathrm{mL}), \mathrm{p}<0.0001$. Nu au fost diferențe pentru concentrația plasmatică a MCP-1 între control $(0,69 \pm 0,18 \mathrm{pg} / \mathrm{mL})$ și FO $(0,798 \pm 0,060 \mathrm{pg} / \mathrm{mL})$, în schimb în grupul ischemic MCP-1 a fost semnificativ mai mare $(1,627 \pm 0,19 \mathrm{pg} / \mathrm{mL}), \mathrm{p}=0,0001$. In timp ce la grupul ischemic nivelul plasmatic a fost crescut în ambele momente ale determinării, la grupul FO concentrația a scăzut semnificativ după 24 de ore $(p=0,0005)$. Acizii grași polinesaturați Omega 3 reduc nivelul plasmatic al MCP-1, citokină cheie implicată în migrarea celulelor inflamatorii. In plus, în grupul precondiționat cu Omega 3, expresia TIMP-1în periferie a fost mai scăzută, probabil datorită unei activări mai reduse a matrix metaloproteinazelor.

Keywords: TIMP-1, MCP-1, MCAO, fish oil, omega-3, cytokines

\section{Introduction}

Ischemic brain injury, which occurs after blood cessation is associated with an increased inflammatory response consisting of inflammatory cells infiltration and consequently enhanced production of cytokines and chemokines along to activation of resident microglia. Leukocyte infiltration is also involved in ischemia-reperfusion injury with excessive production of pro-inflammatory cytokines, chemokines, and MMP (matrix metalloproteins) activation, eventually 
FARMACIA, 2018, Vol. 66, 4

leading to amplification of detrimental conditions in ischemic stroke [8]. Monocyte chemoattractant protein-1 (MCP-1/CCL2) chemokine ligand-2 involved in monocyte-macrophage infiltration is found in very low concentration in normal conditions and overexpressed in middle cerebral artery occlusion (MCAO) model [21], with a peak at $24-48 \mathrm{~h}$ after MCAO, being accompanied by increased inflammatory cells recruitment probably under the over-activation of the endothelium by the proinflammatory cytokines [3]. An increased body of literature revealed the antiinflammatory actions of the Omega 3 fatty acids (FAs) during the ischemic episode in experimental models, acting through multiple pathways [9], from dampening pro-inflammatory cytokines and eicosanoids production, to synthesis of proresolving mediators (resolvins and protectins) when administered before or after MCAO [1, 19]. A recent study revealed a significant decrease in plasma MCP-1 concentration compared to saline, in an ischemia-reperfusion intestinal injury murine model after fish-oil (FO) preconditioning [22].

Additionally, the blood-brain barrier (BBB) disruption and oedema are the consequence of matrixmetalloproteinases (MMPs) activation, especially MMP 9, a key molecule involved in membrane degradation. MMP 9 activity is regulated by TIMP-1 (Tissue inhibitor metalloproteinase-1) by blocking the access to the active site of the enzyme $[5,10]$.

The aim of the study was to assess the dynamic changes in plasma of the above two mentioned cytokines in a transient MCAO (tMCAO) rat model after $\mathrm{FO}$ preconditioning and to evaluate the possible correlations with inflammatory cells in the ischemic region.

\section{Materials and Methods}

\section{Animals and housing}

All experimental protocols were approved by the Ethics Committee of the University of Medicine and Pharmacy of Târgu Mureș, Romania, and were in accordance with the International Council for Laboratory Animal Science guidelines (Directive 2010/63/EU). Wistar male adult rats (280-320g) from the Animal Facility, University of Medicine and Pharmacy Cluj-Napoca, Romania, were kept in a climate- controlled environment with free access to food and water.

\section{Treatment}

Animals were divided into a sham group $(\mathrm{n}=10)$, saline-treated group $(\mathrm{n}=10)$ and highly purified FO phospholipid emulsion $(\mathrm{n}=10)$ preconditioned group. In FO group, the treatment was administered daily (intraperitoneally) for 3 weeks in a dose of 3.5 $\mathrm{mL} / \mathrm{kg}$, corresponding to a concentration of 70 $\mathrm{mg} / \mathrm{kg}$ EPA and $80 \mathrm{mg} / \mathrm{kg}$ DHA. In the saline group, the same volume of saline solution was given using the same route. Although the phospholipid emulsion contains a small concentration of alphatocopherol $(0.02 \mathrm{mg} / \mathrm{mL})$ as an antioxidant component of FAs, we did not consider necessary an additional animal group, treated only with alphatocopherol, because a previous study has shown that this component had no influence on the final ischemic volume compared to saline-treated animals [2]. The phospholipid emulsion used for preconditioning is suitable for parenteral nutrition; the intraperitoneal route of administration [7, 19] was used in order to minimize loss of the active substance; since all groups had the same administration regimen, the potential cytokine growth effect will be minimized. Induction of $M C A O$

Anesthesia was induced in a pre-anesthetic chamber with $3.5 \%$ isoflurane in a mixture of medical oxygen and maintained on breathing mask during the surgical procedure with $1.5 \%$ isoflurane. The body temperature was maintained constant at $37^{\circ} \mathrm{C}$ with a heating pad (Doccol Corporation, USA). Transient ischemia was induced by occluding the right middle cerebral artery with silicon occluder calibrated on the animal weight. A reusable rubbercoated monofilament, size $4-0$, with a total diameter of $0.185 \mathrm{~mm}$ and a coating diameter of $0.39 \pm 0.02 \mathrm{~mm}$ (Doccol Corporation, USA) was used for obstruction of the emergence of the middle cerebral artery (MCA), using a protocol described elsewhere [13]. After 90 min the monofilament was removed under anesthesia (induced by the same protocol). In the sham group, all initial steps before surgery were performed, followed by the carotid artery exposure without its dissection. Pain relief medication and saline were administered for pain reduction and optimal hydration. After recovery from anesthesia, the animals had free access to food and water.

\section{Evaluation of $T M C A O$}

Neurological deficit was evaluated using a 5-points scale after recovering from anesthesia and $24 \mathrm{hrs}$ thereafter. The neurological score was graded from 0-no deficit; 1 - mild deficit (failure to extend the contralateral paw); 2- moderate deficit (circling to the contralateral part); 3- severe deficit (falling towards contralateral to ischemia) and 4- unable to walk spontaneously [20]. Additionally, $24 \mathrm{hrs}$ after reperfusion, magnetic resonance imaging (MRI) was performed under anesthesia with permanent respiratory and cardiac monitoring, in order to evaluate the magnitude of the ischemic lesions. A 7 Tesla Scanner (BrukerBIOSpec 70/16 USR scanner) was used in this regard, using a high-resolution T2 weighted image (T2WI) and TurboRARE 3D protocol for quantification of the ischemic lesion followed by the $3 \mathrm{D}$ reconstruction of the ischemic region.

Blood and tissue sampling and analysis

For peripheral cytokine profile, the blood was withdrawn at $6 \mathrm{hrs}$ after reperfusion from the retroorbital artery, under isoflurane-induced anesthesia in EDTA collection tubes. After MRI acquisition $24 \mathrm{hrs}$ after reperfusion, the animals were re-anesthetized, another blood sample was taken, the brain was perfused, and animals were sacrificed. The brain 
FARMACIA, 2018, Vol. 66, 4

was harvested, washed in $10 \%$ neutral formalin buffer and kept in formalin for 24 hrs for further histological and immunohistochemical (IHC) evaluation. A 5-mm-thick coronal section in the peri-bregma region was embedded in paraffin prior sectioning into a series of $5-6 \mu \mathrm{m}$ thick sections in rostrocaudal direction; $\mathrm{H} \& \mathrm{E}$ (hematoxylin-eosin) and CV (Cresil Violet)/Nissl staining were used in order to identify the ischemic lesion. Sham-operated brains served as controls. Tissue section stained with $\mathrm{CV}$ were digitalized and quantified with Image $\mathrm{J}$ program [23] the infarct area was expressed as a percentage of total brain volume with correction for brain oedema [19]. Morphometric analysis of specific cells changes was performed by the scoring scheme recommended by Randell at al [14]. Focal acute eosinophilic necrosis associated with neural cell vacuolization, neural degeneration with pycnotic nucleus associated with vacuolization of neuropils, cell edema and the presence of inflammatory cells were considered the most important aspects to be evaluated for analysis, both in core and penumbra. For each parameter, a score ranging from 1 - 10 has been granted (expressed as mean $\pm \mathrm{SD}$ ); finally, a total score was obtained by summarizing all above morphological changes; a high score was suggestive for a greater deterioration.

Inflammatory infiltrate (neutrophils, macrophages, CD4 and CD8 $T$ cells) involved in the focal ischemia and reperfusion were evaluated in the core and penumbra using following specific markers: anti-CD15 clone Carb-3 (Dako), anti-CD68 EKP1 ab955, anti-CD3 SP7 ab 21703, anti-CD4 ab 203034, anti-CD8 ab 17147 (Abcam). Expressions of intracerebral enzymes were analyzed as follow: for MMP-9, anti-MMP-9 ab 15W2 (Novocastra) was used, anti-COX-2 ab CX-294 (Dako) for COX 2 expressions and anti-Factor XIII a clone E980.1 (Novocastra) for FXIII expressions. Immunocomplexes were visualized with Goat Anti-Mouse $\operatorname{IgG}$ and Goat Anti-Rabbit IgG and revealed with 3,3'-diaminobenzidine chromogen (DAB) followed by haematoxylin counterstain. As a positive endogen control, the contralateral non-ischemic hemisphere was used, while as a negative control the antibodies were replaced by normal serum. All immunostained sections were analysed and assessed individually by two examinators and discrepancies of their findings were discussed, and a consensus was reached. Results of the comparative study of the profile of inflammatory cell types represented by a median \pm SD value of positive cells surface ( $\%$ of the total area) in the core and penumbra.

Cytokines detection

Five cytokines, Il-6, TNF-alfa, VEGF, MCP-1, and TIMP-1 were analyzed with XMAP technology (EMD Millipore, Merck, Germany) on FlexMap 3D analyzer (Luminex, Austin, USA). xMAP beads-based technology is designed in a multiplex fashion, enabling the evaluation of multiple proteins in a small amount of sample, by flow-cytometry at the end of an immune reaction. The magnetic beads are internally colored in a variety of colors from red to infrared, which are identified by a red laser, while the green laser will quantify the amount of bound protein based on the fluorescent signal.

Statistical analysis

Data were expressed as a mean \pm standard error of the mean (SEM) or median and were compared using the Student's t-test or Mann-Whitney test, as appropriate. Repeated measures analysis of variance (ANOVA), followed by Bonferroni procedure to correct multiple comparisons were performed. A two-tailed p-value of less than 0.05 was considered statistically significant.

\section{Results and Discussion}

After the behavioural evaluation post tMCAO, only animals with at least 2 points deficit on the neurological scale were used for further investigations. At the end of the study, 2 animals died in the saline-treated group, and one animal did not show a motor deficit

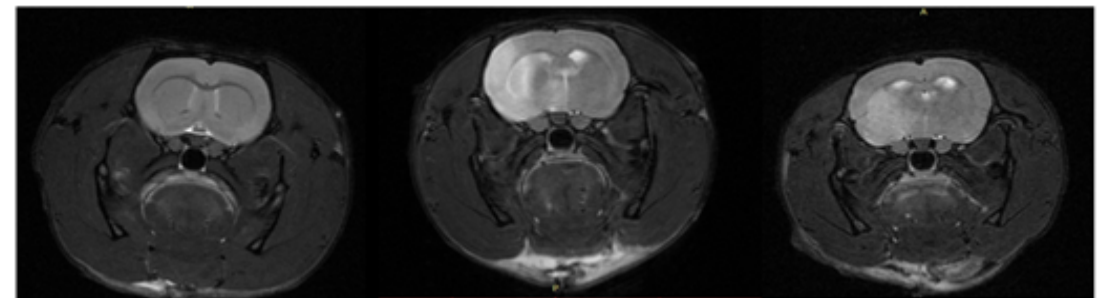

Figure 1.

A representative MRI acquisition image for sham (left), saline (middle) and FO preconditioned (right).

The ischemic region is visualized as a white zone in the striatum and subcortical area (for each MRI acquisition a 32 slice protocol was used; the images displayed above are for the 16th slice).

Effects of FO preconditioning on infarct area evaluated by MRI

Imagistic evaluation at $24 \mathrm{hrs}$ after tMCAO, clearly revealed the dimension of the ischemic area (Figure1); a T2 weighted image (T2WI) revealed the ischemic region as a white area clearly delineated by the normal brain tissue (middle and right handed-part) compared to nonischemic brain (left-handed part). 
FARMACIA, 2018, Vol. 66, 4

Effects of FO administration on plasma lipids and liver

Plasma lipids (total cholesterol and triglycerides) and liver cytolytic enzymes (AST and ALT) were analysed (Cobas Integra 400 plus, Roche Diagnostics); no difference between saline and FO group were found for all studied biochemical parameters analyzed at the end of the study ( $p>0.05$, data not shown).
Effects of $F O$ administration on peripheral cytokine levels

The peripheral changes in plasma cytokine levels for each group are detailed in Table I. There was no difference inside each group regarding concentrations of IL-6, VEGF and TIMP-1 measured at $6 \mathrm{hrs}$ versus 24 hrs after MCAO; in FO group TNF-alfa and $\mathrm{MCP}-1$ concentrations decreased significantly between the two measurements.

Table I.

Dynamic evolution of plasma cytokine levels in sham (S), ischemic (I) and FO groups

\begin{tabular}{|c|c|c|c|c|c|c|c|c|c|}
\hline \multirow{2}{*}{$\begin{array}{l}\text { Analyte } \\
(\mathrm{pg} / \mathrm{mL})\end{array}$} & \multicolumn{2}{|c|}{$\mathbf{S}$} & \multirow[t]{2}{*}{$p$} & \multicolumn{2}{|c|}{ I } & \multirow[t]{2}{*}{$p$} & \multicolumn{2}{|c|}{ FO } & \multirow[t]{2}{*}{$p$} \\
\hline & $\begin{array}{l}6 \mathrm{hrs} \\
(\mathrm{n}=7)\end{array}$ & $\begin{array}{l}24 \mathrm{hrs} \\
(\mathrm{n}=9)\end{array}$ & & $\begin{array}{l}6 \mathrm{hrs} \\
(\mathrm{n}=7)\end{array}$ & $\begin{array}{l}24 \mathrm{hrs} \\
(\mathrm{n}=7)\end{array}$ & & $\begin{array}{c}6 \mathrm{hrs} \\
(\mathrm{n}=10)\end{array}$ & $\begin{array}{c}24 \mathrm{hrs} \\
(\mathrm{n}=10)\end{array}$ & \\
\hline IL-6 & $0.205 \pm 0.050$ & $0.166 \pm 0.007$ & ns & $0.588 \pm 0.100$ & $0.428 \pm 0.020$ & ns & $1.462 \pm 0.690$ & $1.259 \pm 0.590$ & ns \\
\hline $\begin{array}{l}\text { TNF } \\
\text { alfa }\end{array}$ & $32.67 \pm 2.35$ & $33.20 \pm 2.13$ & ns & $65.43 \pm 5.62$ & $59.71 \pm 2.08$ & ns & $71.90 \pm 2.84$ & $62.00 \pm 2.31$ & $*$ \\
\hline VEGF & $0.048 \pm 0.010$ & $0.038 \pm 0.010$ & ns & $0.178 \pm 0.090$ & $0.226 \pm 0.117$ & ns & $0.213 \pm 0.136$ & $0.269 \pm 0.171$ & ns \\
\hline TIMP-1 & $10.35 \pm 1.54$ & $8.69 \pm 0.94$ & ns & $30.24 \pm 8.43$ & $37.28 \pm 4.85$ & ns & $15.49 \pm 3.19$ & $14.22 \pm 1.79$ & ns \\
\hline МСР-1 & $0.938 \pm 0.310$ & $0.690 \pm 0.187$ & ns & $1.516 \pm 0.26$ & $1.627 \pm 0.194$ & ns & $1.389 \pm 0.142$ & $0.798 \pm 0.060$ & $* *$ \\
\hline
\end{tabular}

IL - interleukin, TNF - tumour necrosis factor, VEGF - vascular endothelial growth factor, TIMP - tissue inhibitor matrix

metalloproteinase, MCP - monocyte chemoattractant factor; values expressed as a mean \pm standard error of the mean (SEM); ns $=$ no significant differences, ${ }^{*} \mathrm{p}<0.05, * * \mathrm{p}<0.01$

Between groups comparison (Table II) revealed that TNF-alfa levels were significantly higher in ischemic and FO group compared to sham, both at 6 and 24 hrs $(\mathrm{p}<0.0001)$. MCP-1 measured at 24 hrs is significantly higher compared to sham and
FO group $(\mathrm{p}=0.0004)$, while TIMP-1 was elevated in the same group at both time-point analysed $(\mathrm{p}=$ 0.034 for 6 hrs measurement and $p<0.0001$ for 24 hrs measurement).

Dynamic changes in plasma cytokine levels between group comparison at 6 hrs and 24 hrs after reperfusion

\begin{tabular}{|c|c|c|c|c|}
\hline Analytes (pg/mL) & Sham (group 1) & Ischemic (group 2) & Fish Oil (group 3) \\
\hline TNF alfa, 6 h & $32.67 \pm 2.35$ & $87.14 \pm 5.92$ & $71.90 \pm 2.84$ \\
\hline TNF alfa, 24 h & $33.20 \pm 2.14$ & $81.43 \pm 4.44$ & $62.00 \pm 2.31$ \\
\hline IL-6, 6 h & $0.205 \pm 0.05$ & $0.588 \pm 0.105$ & $1.462 \pm 0.69$ \\
\hline Il-6, 24 h & $0.166 \pm 0.007$ & $0.488 \pm 0.016$ & $1.259 \pm 0.59$ & 0.0001 \\
\hline VEGF 6 h & $0.048 \pm 0.02$ & $0.178 \pm 0.09$ & $0.213 \pm 0.14$ & 0.118 \\
\hline VEGF 24 h & $0.038 \pm 0.01$ & $0.226 \pm 0.11$ & $0.269 \pm 0.171$ \\
\hline MCP-1, 6 h & $0.938 \pm 0.31$ & $1.516 \pm 0.26$ & $1.389 \pm 0.14$ & 0.351 \\
\hline MCP-1, 24 h & $0.69 \pm 0.18$ & $1.627 \pm 0.19$ & $0.798 \pm 0.060$ \\
\hline TIMP-1, 6 h & $10.35 \pm 1.54$ & $30.24 \pm 8.43$ & $15.49 \pm 3.19$ \\
\hline
\end{tabular}

Values expressed as a mean \pm standard error of the mean (SEM); p obtained from ANOVA with Bonferroni correction for multiple comparisons. IL - interleukin, TNF - tumour necrosis factor, VEGF - vascular endothelial growth factor, TIMP - tissue inhibitor matrix metalloproteinase, MCP - monocyte chemoattractant factor

Brain morphological and IHC changes after FO administration

The most important morphological modifications in the ischemic area, visualized with HE stains, were neural degeneration and oedema (A), pycnotic nucleus and vacuolization (B) along with focal eosinophilic necrosis (C). Also, an important inflammatory infiltrate (D) has been identified around the ischemic tissue. A morphological total score $(\mathrm{A}+\mathrm{B}+\mathrm{C}+\mathrm{D})$ calculated separately for saline group $30.2 \pm 2.77$ and FO group $25.8 \pm 4.32$, was found at the limit of statistical significance $(\mathrm{p}=0.09)$, however the inflammatory infiltrate was significantly lower in FO group (2.4 \pm $0.55)$, compared to saline-treated group $(5 \pm 0.71)$, $(\mathrm{p}=0.0002)$.

Expression of CD4+ and CD8+ Lymphocytes differed neither in the core nor in the penumbra, both in the saline-treated and FO preconditioned rats. However, CD15 and CD68 expressions were higher in the penumbra in the saline-treated group compared to FO-treated rats $(p=0.001$ for CD15 and $p=0.003$ for CD68). 
FARMACIA, 2018, Vol. 66, 4

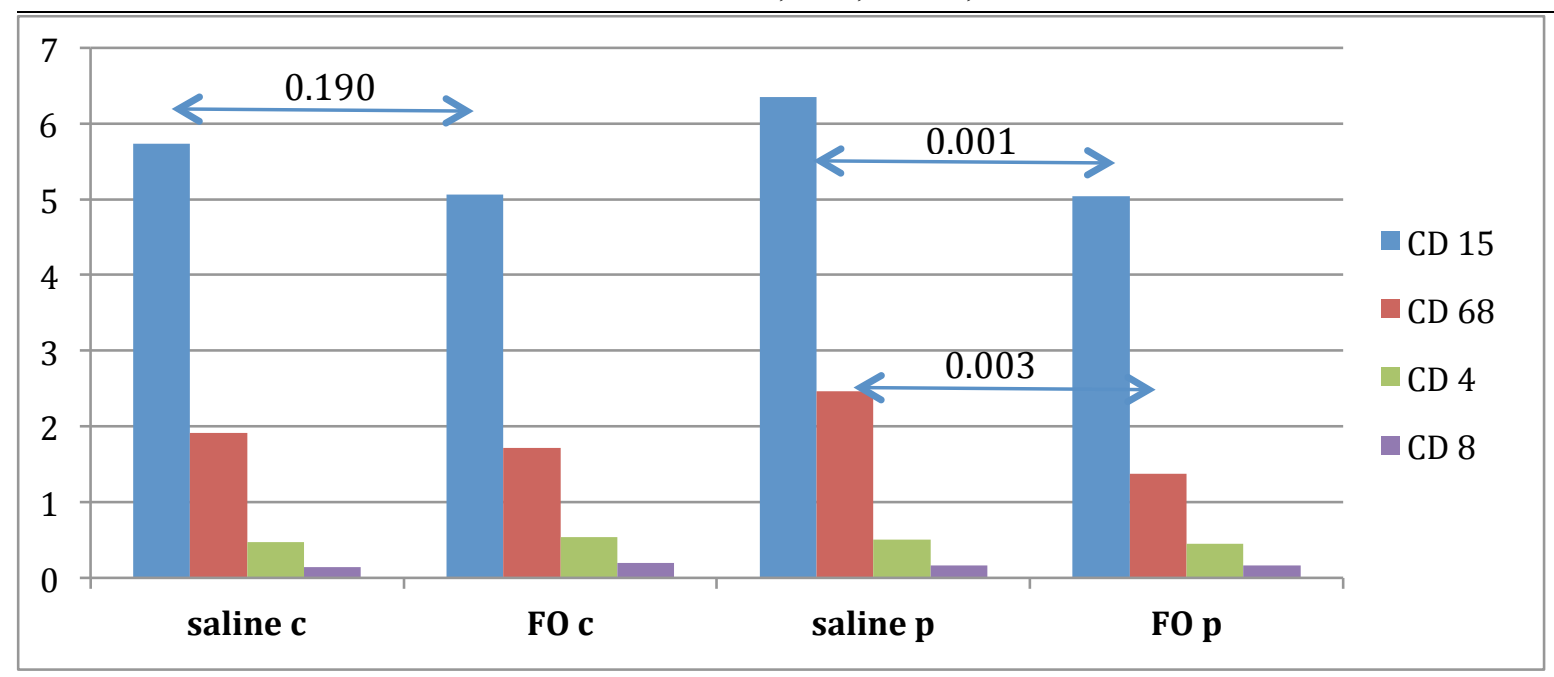

Figure 2.

The comparative study of immune cells expression in core and penumbra for saline and FO treated rats $\mathrm{c}=$ core, $\mathrm{p}=$ penumbra; $\mathrm{CD} 15=$ cluster of differentiation marker for neutrophils; $\mathrm{CD} 68=$ marker for microglia and macrophages

Expressions of studied enzymes in the ischemic hemisphere in saline and FO treated rats are depicted in Figure 3. The MMP-9 expression is significantly higher both in core and penumbra in the salinetreated group compared to FO group $(\mathrm{p}=0.001$ for core and; $p=0.002$ for penumbra), while the expressions of COX-2 and FXIII are higher in penumbra in saline compared to FO group ( $\mathrm{p}=$ $0.001)$.

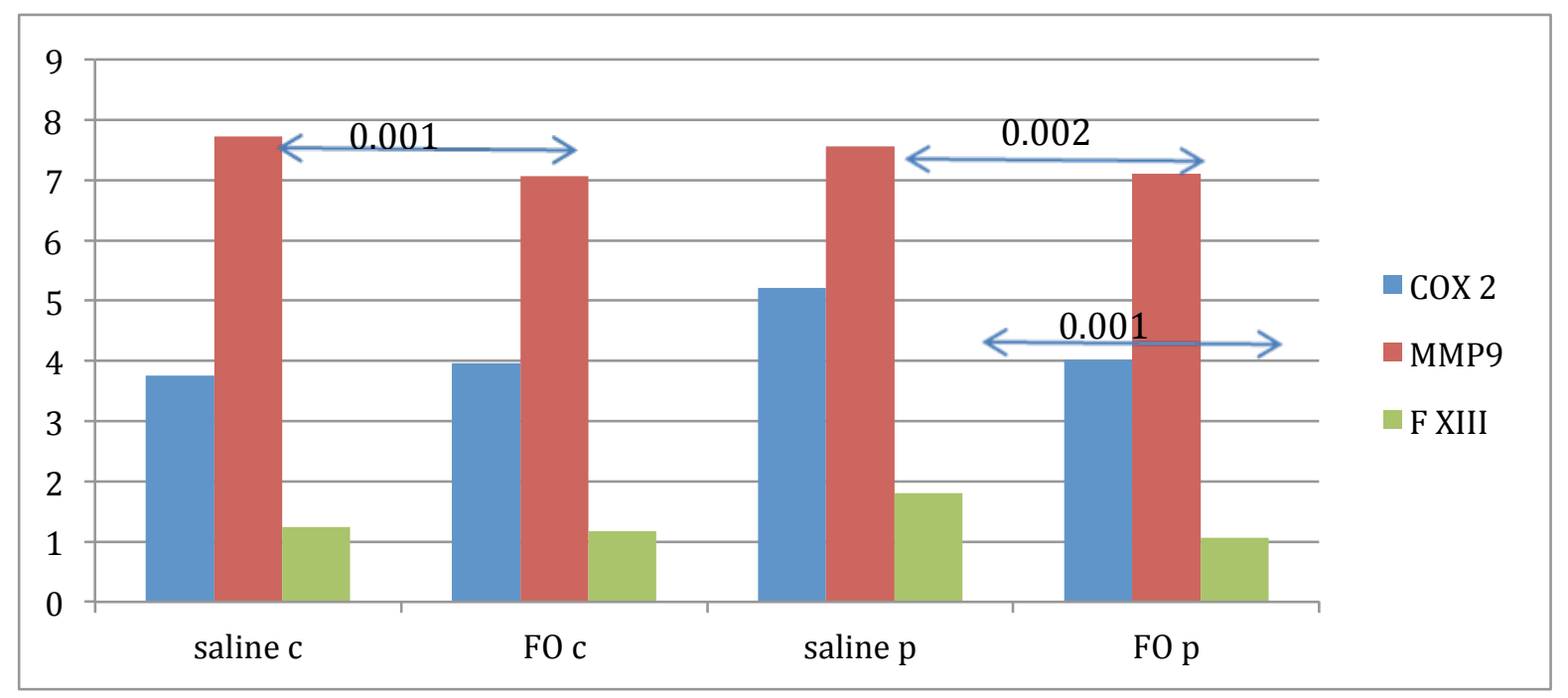

Figure 3.

Comparative expression of MMP-9, COX-2, and FXIII in core and penumbra in saline and FO treated rats MMP-matrix- metalloproteinase 9; COX-2- cyclooxygenase-2; F XIII=blood coagulation factor XIII.

The aim of the study was to assess the dynamic changes in peripheral plasma cytokine levels in ischemic rats with and without Omega 3 preconditioning. Additionally, the possible correlation between plasma cytokine and morphological cerebral features were analysed. Cerebral ischemia was induced for 90 minutes using the intravascular suture technique. Behavioural and MRI tests were performed for evaluation of the magnitude of ischemic lesions.

The morphological analysis revealed that the inflammatory infiltrates in the ischemic hemisphere, expressed as the presence of neutrophils, monocytes and lymphocytes are significantly lower in Omega 3 preconditioned group compared to the salinetreated group. The morphological changes were in concordance with IHC results, expression of CD15, CD68, and CD3 in penumbra being more pronounced in the saline-treated group compared to fish oil group. After reperfusion, infiltration of neutrophils and monocytes represents an important source of free radicals and MMP-9 thus aggravating the postischemic damages, irrespective of the time elapsed from the ischemic onset [6]. A literature review revealed the early neutrophils infiltration is followed by infiltration with $\mathrm{T}$ lymphocytes and macrophages 
FARMACIA, 2018, Vol. 66, 4

with the amplification of inflammatory processes [6]. Our results suggest that $24 \mathrm{hrs}$ after reperfusion the penumbra was infiltrated with neutrophils, and CD3 positive lymphocytes. Fish oil preconditioning significantly reduces the expression of CD15, CD68 and CD3 positive cell population in the penumbra compared to saline-treated group. MMP9 secreted also by neutrophils is highly expressed both in core and penumbra in saline-treated compared to FO preconditioned group. Plasma MCP-1 concentration was significantly correlated with CD15 expression in penumbra in ischemic group $(\mathrm{r}=0.928, \mathrm{p}=0.006)$, proving the involvement of this chemokine in early infiltration, more augmented in saline-treated group. In FO supplementation group, MCP-1 concentration after $24 \mathrm{hrs}$ decreased, while in saline-treated the concentration raised instead, suggesting a reduction in neutrophil infiltration, an important source of MMP-9.

COX-2 is an enzyme secreted under pathological condition by various cell types, involved in prostaglandins and thromboxane synthesis from arachidonic acid. A recent study of a pathological condition involving the hypoxic status (arthritis), revealed a mitochondrial dysfunction COX-2 mediated, leading to increased tissular destruction [18]. The COX-2 transcription and protein expression in endothelial cells was reduced by DHA throughout blocking NF-kB and decreasing the ERK1/2 activation [12]. In our study, the COX-2 expression in penumbra was significantly reduced in FO preconditioned compared to the saline-treated group, suggesting the protective role of Omega 3 constituents on COX-2 activity.

Another interesting finding was the increased expression of FXIII in penumbra in the salinetreated group, especially in CD68 positive cells, suggesting a relationship between this factor and cell activation. The fibrin stabilizing factor (FXIII), secreted mainly by platelets and monocytes/macrophages with dual effects: beneficial effect on healing processes but also with deleterious implications due to thrombus formation. Recently this marker has been studied as a marker of alternative activation of macrophages [4]. In ischemic patients, the plasma levels of FXIII was found in correlation with stroke severity [16]. In our study the expression of FXIII was significantly higher in penumbra in salinetreated group, compared to FO group, suggesting the possible influence of Omega 3 in activation of FXIII.

TIMP-1 is an endogenous inhibitor of MMPs expressed only in pathological conditions; the suppression of TIMP-1 increasing MMP-9 activation and enhancing BBB disruption [11]. An experimental study on transgenic mouse overexpressing TIMP-1 revealed milder $\mathrm{BBB}$ destruction after traumatic brain injury [11], while mouse with TIMP-1 -/- had higher MMP-9 concentration and activity, with increased BBB disruption and neuronal apoptosis
[5]. Experimental study shows a correlation between brain concentration of DHA and TIMP-1 expression, however, no connection with MMP-9 activity was proven, suggesting that TIMP-1 exerts antiapoptotic activity independent of MMP-9 inhibition [15]. In our study, in the pre-treated group, MMP-9 expression in core and penumbra was significantly lower with a reduced peripheral level of TIMP-1, suggesting that TIMP-1could reflect the response to MMP-9 activation.

Our study brings additional information about the Omega 3 supplementation in brain pathologies [17], namely related to the dynamic evolution of peripheral cytokines in experimental induced ischemia, especially on FXIII yet poorly investigated in literature in relation to inflammatory processes in ischemic stroke. The small number of animals could be a potential limitation of the study, with a projection on the statistical power. Also, we did not analyse the brain or plasma FA concentration, thus we were unable to correlate the levels of the cytokine with brain DHA and EPA incorporation. Another limitation of the study was the non-evaluation of plasma MMP-9 concentration, thus the inability to use the MMP9/TIMP-1 ratio as a predictive marker of BBB destruction.

\section{Conclusions}

Plasma concentration of TNF alfa and MCP-1 and TIMP-1 was reduced in fish oil preconditioned group in experimental induced cerebral ischemia. Additionally, inflammatory cells were significantly under expressed in the penumbra, while MMP-9 had decreased expression both in core and penumbra in fish oil pre-conditioned animals.

\section{Funding Sources}

This research was supported by an Internal Research Grant from the University of Medicine and Pharmacy Târgu-Mureș, România (Number $17803 / 1 / 22.12 .2015)$.

\section{Acknowledgements}

The authors thank the "Studium Prospero Foundation" (România) for partial financial support.

\section{Conflicts Of Interest}

The authors declare that they have no conflict of interest.

\section{References}

1. Belayev L, Khoutorova L, Atkins KD, Bazan NG, Robust docosahexaenoic acid-mediated neuroprotection in a rat model of transient, focal cerebral ischemia. Stroke; a Journal of Cerebral Circulation, 2009; 40(9): 3121-3126. 
FARMACIA, 2018, Vol. 66, 4

2. Berressem D, Koch K, Franke N, Klein J, Eckert GP, Intravenous Treatment with a Long-Chain Omega-3 Lipid Emulsion Provides Neuroprotection in a Murine Model of Ischemic Stroke - A Pilot Study. PloS One, 2016; 11(11): e0167329.

3. Chen Y, Hallenbeck JM, Ruetzler C, Bol D, Thomas K, Berman NE, Vogel SN, Overexpression of monocyte chemoattractant protein 1 in the brain exacerbates ischemic brain injury and is associated with recruitment of inflammatory cells. J Cereb Blood Flow Metab., 2003; 23: 748-755.

4. Esnault S, Kelly EA, Sorkness RL, Evans MD, Busse WW, Jarjour NN, Airway factor XIII associates with type 2 inflammation and airway obstruction in asthmatic patients. J Allergy Clinical Immunology, 2016; 137(3): 767-773.

5. Fujimoto M, Takagi Y, Aoki T, Hayase M, Marumo T, Gomi M, Nozaki K, Tissue inhibitor of metalloproteinases protect blood-brain barrier disruption in focal cerebral ischemia. $J$ Cerebral Blood Flow Metab., 2008; 28(10): 1674-1685.

6. Gronberg NV, Johansen FF, Kristiansen U, Hasseldam $\mathrm{H}$, Leukocyte infiltration in experimental stroke. $J$ Neuroinflammation, 2013; 10: 115.

7. Iamandei G, Iamandei $\mathrm{G}$, Mocanu V, Oboroceanu $\mathrm{T}$, Luca V, Involvement of N6 and N3 polyunsaturated faty acids on the lipidic profile in central nervous system of the animals of experience. Romanian Neurosurgery, 2010; XVII(4): 396-402.

8. Jin R, Yang G, Li G, Inflammatory mechanisms in ischemic stroke: role of inflammatory cells. J Leukocyte Biology, 2010; 87(5): 779-789.

9. Kang JX, Weylandt KH, Modulation of Inflammatory Cytokines by Omega-3 Fatty Acids. In Lipids in Health and Disease Dordrecht: Springer Netherlands. 2008: 133-143.

10. Kim Y, Remacle AG, Chernov AV, Liu H, Shubayev I, Lai C, Shubayev VI, The MMP-9/TIMP-1 Axis Controls the Status of Differentiation and Function of Myelin-Forming Schwann Cells in Nerve Regeneration. PLoS ONE, 2012; 7(3): e33664.

11. Lakhan SE, Kirchgessner A, Tepper D, Leonard A, Matrix metalloproteinases and blood-brain barrier disruption in acute ischemic stroke. Frontiers in Neurology, 2013; 32.

12. Massaro M, Habib A, Lubrano L, Del Turco S, Lazzerini G, Bourcier T, De Caterina R, The omega-3 fatty acid docosahexaenoate attenuates endothelial cyclooxygenase-2 induction through both NADP(H) oxidase and PKC epsilon inhibition. Proceedings of the National Academy of Sciences of the United States of America, 2006; 103(41): 15184-15189.
13. Orădan A, Huțanu A, Horváth E, Chiriac L, Dobreanu $\mathrm{M}$, Improved rat stroke model by intraluminal middle cerebral artery occlusion: a special emphasis on surgical technique. Health Problems of Civilization, 2017; 11(3): 200-210.

14. Randell A, Chokshi K, Kane B, Chang H, Naiel S, Dickhout JG, Daneshtalab N, Alterations to the middle cerebral artery of the hypertensive-arthritic rat model potentiates intracerebral hemorrhage. Peer $J$, 2016; 4(Cv): e2608.

15. Russell KL, Berman NEJ, Levant B, Low brain DHA content worsens sensorimotor outcomes after TBI and decreases TBI-induced Timp1 expression in juvenile rats. Prostaglandins Leukotrienes and Essential Fatty Acids, 2013; 89(2-3): 97-105

16. Schroeder V, Ortner E, Mono ML, Galimanis A, Meier N, Findling O, Kohler HP, Coagulation factor XIII activation peptide and subunit levels in patients with acute ischaemic stroke: A pilot study. Thrombosis Research, 2010; 126(2): e122-e127.

17. Tarţa-Arsene O, Leanca M, Dică A, Bran E, Rad F, Timnea O, Păcurar D, Velescu BȘ, Nicolae AC, Drăgoi CM, Dietary omega-3 fatty acids supplimentation for attention deficit with hyperactivity disorder in epileptic children. Farmacia, 2017; 65(4): 550-556.

18. Valcárcel-Ares MN, Riveiro-Naveira RR, VaamondeGarcía C, Loureiro J, Hermida-Carballo L, Blanco FJ, López-Armada MJ, Mitochondrial dysfunction promotes and aggravates the inflammatory response in normal human synoviocytes. Rheumatology, 2014; 53(7): 1332-1343.

19. Williams JJ, Mayurasakorn K, Vannucci SJ, Mastropietro C, Bazan NG, Ten VS, Deckelbaum RJ, N-3 fatty acid rich triglyceride emulsions are neuroprotective after cerebral hypoxic-ischemic injury in neonatal mice. PloS One, 2013; 8(2): e56233.

20. Woodruff TM, Thundyil J, Tang SC, Sobey CG, Taylor SM, Arumugam TV, Pathophysiology, treatment, and animal and cellular models of human ischemic stroke. Molecular Neurodegeneration, 2011; 6(1): 11.

21. Yamagami S, Tamura M, Hayashi M, Endo N, Tanabe H, Katsuura Y, Komoriya K, Differential production of MCP-1 and cytokine-induced neutrophil chemoattractant in the ischemic brain after transient focal ischemia in rats. J Leukoc Biol., 1999; 65: 744-749.

22. Zhang R, He G, Wang Y, Zhou K, Ma E, Omega-3 polyunsaturated fatty acids inhibit the increase in cytokines and chemotactic factors induced in vitro by lymph fluid from an intestinal ischemia-reperfusion injury model. Nutrition (Burbank, Los Angeles County, Calif.), 2015; 31(3): 508-514.

23. $* * *$ http://imagej.nih.gov/. 